\title{
The Mathematical Analysis of Dao De Ching (DDC)—The Set Study of DDC
}

\author{
WANG Tongjun \\ Beijing International Studies University (BISU), Beijing, China
}

\begin{abstract}
This paper aims to interpret Dao De Ching (DDC) in terms of mathematical set theory. It employs the set study to demonstrate DDC, the first philosophy, the Chinese Bible. Properties of sets can well illustrate what is going on in this verse. DDC consists of a set of Dao and De, or a set of Dao, with all the components in the universe, the nature, or the human world, of which De can be rendered as its subset, the performances of myriad things. A host of terms, like Dao, De, Being (You), Non-being (Wu), Yin, Yang, Non-action (Wuwei), Spontaneity (Ziran), all are sets or subsets, fuzzy sets to be exact. Fields, group theory, Venn diagram, fuzzy sets all are playing substantial role in appreciating the book. DDC is a conjoined twin baby with a head (Ching) and two bodies (Dao and De); mathematics can dissect it.
\end{abstract}

Keywords: Dao De Ching (DDC), Dao, De, mathematics, sets

\section{Introduction}

A philosopher says, "without mathematics, we cannot see through the philosophy; without philosophy, math cannot be profoundly appreciated; without these two, nothing we can go deeper about". To highly analysize Dao De Ching (DDC), the first philosophy in China, the so-called Chinese Bible, it is necessary for us to handle it in the perspective of math. Math emphasizes quantity, while philosophy focuses on quality (Zhang, 2017, p. 6). The mathematical analysis of Daoism is a kind of approach to weigh the quality based on quantity tools under the banner of mathematics. Philosophy, to some extent, is a sort of telescope, and math seems to be a microscope. The vague philosophy and precise mathematics are two actors in the same stage (Zhang, 2011, p. 157). Philosophy studies the concrete object abstractly; while math concretely goes into something abstract (p. 160). A good mathematical analysis of it will provide thorough and illuminating understanding of the intellectual landscape of the gnosis, whose knowledge involves nature and the human life.

It is said that math's coming into a subject reflects its establishment, while the escape of philosophy from it demonstrates its mature (p. 157). The introduction of math into the analysis of the Daoism can render the stride of the research.

Funding: The author is grateful for research support from the project "Legal Translating in the Perspectives of Daoism and Mathematics" (WHCB18B001), Beijing Research Center for International Culture Exchange.

WANG Tongjun, Master of English Literature \& Master of Business Law, associate professor, College of English Language, Beijing International Studies University (BISU), Beijing, China. 
Mathematics is a way of thinking that can help make muddy relationships clear. It is a language that allows us to translate the complexity of the world into manageable patterns. DDC offers us a way of thinking of the universe, all things in nature, whose relations are hard to define. That is the very mystery of Dao, which is also the main theme for this paper. Math allows you strip off the coverings and get right down to skeleton (Cole, 1999, p. 7). Can math help us to get rid of the cover of DDC, and go deeper to the heart of it, seeking the truth? What are the hidden connections?

DDC, the D-theory, can be called E-theory, a theory of everything, or M-theory, "master", "mystery", "miracle" theory. Deciphering it with math, the M-tool, invites skilled math intuition and better understanding of this philosophical book. This baby, a theory of DDC under math, may be tender and rough, little and unfamiliar, and there are problems; however, it may be a huge breakthrough.

\section{The Set of DDC}

A set is a collection of objects, either concrete or abstract. A subset of a set is a collection that is contained within the large set (Stark \& Woods, 2012, p. 20). DDC is a set of Dao as well as De, or we can say it is a set of Dao; its elements include all the things in the world, the nature or the human world; De is its subset, whose factors are the concrete things, the manifestations and mirrors of the myriad things.

\subsection{The Set Interpretations of DDC}

In mathematical terms, Dao $=\{1,2,3, \ldots \mathrm{n}, \ldots\}$, which is a listed set. Also, we can describe it as follows: $\operatorname{DDC}(\mathrm{x})=\{\mathrm{x} \mid \mathrm{P}(\mathrm{x})\}$ (P stands for property), $\mathrm{DDC}(\mathrm{x})=\{\mathrm{x} \mid \mathrm{x}=\mathrm{D}(\mathrm{e})+\mathrm{D}(\mathrm{a})=\mathrm{a}+\mathrm{bi}, \mathrm{x} \in \mathrm{C}, \mathrm{a} \in \mathrm{R}, \mathrm{b} \in \mathrm{R}\}$, where De, $a$, is real part; Dao, $b i$, is the imaginary part. In another word, we can define it like this: $\mathrm{D}(\mathrm{x})=\{\mathrm{x} \mid \mathrm{P}(\mathrm{x})$, $\mathrm{x} \in \mathrm{C}\}, \mathrm{C}=\mathrm{a}+\mathrm{bi}$; $\mathrm{C}$ is complex numbers. Put it differently, we can say $\mathrm{D}(\mathrm{a})=\mathrm{C}=\mathrm{a}+\mathrm{bi}, \mathrm{D}(\mathrm{e})=\{\mathrm{x} \mid \mathrm{x}=\mathrm{a}\}, \mathrm{a}$ $\in \mathrm{R}$ (real number), $\mathrm{D}(\mathrm{e}) \subseteq \mathrm{D}(\mathrm{a}), \mathrm{D}(\mathrm{e})=\mathrm{D}(\mathrm{a})$.

Dao $=\{$ nature $\}=\{$ Being, Non-being $\}=\{$ yin, yang $\}=\{$ heaven, earth, humans $\}=\{$ substance, , spirit, rules $\}$ $=\{$ philosophy, ethics, politics, military, cultures, science, religion... $\} ;$ Dao $=$ Rule of Three $=\{$ body, spirit, soul $\}$ $=$ Rule of Four $=\{$ Dao, heaven, earth, King $\}=\{$ one, two, three, all things $\}$

The sets of Self-cultivation, Governance, Military, and Longevity are all subsets. $\mathrm{D}(\mathrm{a})=$ \{metal, wood, water, fire, earth\}.

Also, Dao can be viewed as an empty set, which is an imaginary bag, full of Qi, energy.

The union (sum) of two sets $\mathrm{E}$ and $\mathrm{F}$, written $\mathrm{E} \cup \mathrm{F}$ or $\mathrm{E}+\mathrm{F}$, is the set of all elements that are in at least one of the sets $\mathrm{E}$ and $\mathrm{F}$. The intersection or set product of two sets $\mathrm{E}$ and $\mathrm{F}$, written $\mathrm{E} \cap \mathrm{F}$ or just $\mathrm{EF}$, is the set of elements common to both $\mathrm{E}$ and $\mathrm{F}$. The complement of a set $\mathrm{E}$, written $\mathrm{E}$ '. The operation of unions, intersections, and so forth can be illustrated by Venn diagrams, which are useful as aids in reasoning and in establishing probability relations (Stark \& Woods, 2012, pp. 22-23). The set Dao De Ching $=\{\mathrm{DDC} \mid \mathrm{P}(\mathrm{DDC}\}=\mathrm{D}(\mathrm{a}) \cup \mathrm{D}(\mathrm{e})$, $\mathrm{D}(\mathrm{a}) \cap \mathrm{D}(\mathrm{e})=\mathrm{D}(\mathrm{a})=\mathrm{D}(\mathrm{e}), \mathrm{D}(\mathrm{a})^{\prime}=\mathrm{D}(\mathrm{e})$. If $\mathrm{D}(\mathrm{a})+\mathrm{D}(\mathrm{e})=1$, hence, $\mathrm{D}(\mathrm{a})=1-\mathrm{D}(\mathrm{e})=1-\mathrm{D}(\mathrm{a})^{\prime}$.

$$
y=D(x)=\left\{\begin{array}{l}
1, x \in D(e), x \in R \\
\quad D D C=\{\text { yin, yang }\}=\{y, y\} \\
0, x \in D(a), x \in C
\end{array}\right.
$$




\subsection{Fields and DDC}

A field is a set $\mathrm{F}$ with two operations, called addition and multiplication, which satisfy the following so-called "field axioms" (A), (M), and (D) (Rudin, 2016, p. 5).

(A) Axioms for addition

$$
\text { If } \mathrm{D}(\mathrm{a}) \in\{\mathrm{DDC}\}, \mathrm{D}(\mathrm{e}) \in\{\mathrm{DDC}\} \text {, then } \mathrm{D}(\mathrm{a})+\mathrm{D}(\mathrm{e}) \in\{\mathrm{DDC}\} \text {. }
$$

(M) Axioms for multiplication

$$
\text { If } \mathrm{D}(\mathrm{a}) \in\{\mathrm{DDC}\}, \mathrm{D}(\mathrm{e}) \in\{\mathrm{DDC}\} \text {, then } \mathrm{D}(\mathrm{a}) * \mathrm{D}(\mathrm{e}) \in\{\mathrm{DDC}\} .
$$

(D) The distributive law

$$
\mathrm{C}(\mathrm{h}) *[\mathrm{D}(\mathrm{a})+\mathrm{D}(\mathrm{e})]=\mathrm{D}(\mathrm{a}) * \mathrm{C}(\mathrm{h})+\mathrm{D}(\mathrm{e}) * \mathrm{C}(\mathrm{h}) .
$$

In (A), based on counting principle, $\mathrm{D}(\mathrm{a})$ and $\mathrm{D}(\mathrm{e})$ are two distinctive events, the sum of which reflects DDC's components or elements. Yet, in (M), to reach DDC, $\mathrm{D}(\mathrm{a})$ and $\mathrm{D}(\mathrm{e})$ are two specific steps, the combination of which completes the process, where $\mathrm{D}(\mathrm{a})$ cannot go perfect without $\mathrm{D}(\mathrm{e})$, forming a unit of DDC. In (D), C(h) is the Ching, the views of the object, two of which are Dao Ching and De Ching. These two parts are integrated into DDC.

\subsection{The Venn Diagram of DDC}

Dao De Ching

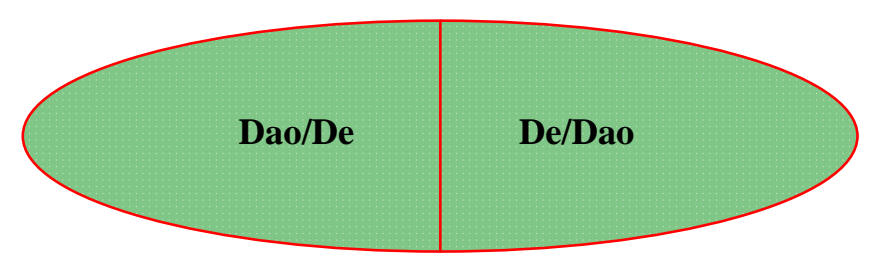

Dao and De are just like the two sides of a coin, with Dao the head and De the tail. Actually, they are mirroring mutually. DDC is a siamese twin, Ching, the head, Dao and De, the body.

\subsection{The Subsets of DDC}

Verse $1, \mathrm{~V}(1)=\{1 \mid 1=$ Dao $=$ Obscure $/$ Fuzzy $/$ Vague $)=$ Non-being $(W u)=$ Being $(Y o u)=$ Non-being $(W u)+$ Being $(Y o u)\}$; in short, $\mathrm{V}(1)=\mathrm{D}(\mathrm{a})=\mathrm{O} / \mathrm{F} / \mathrm{V}=\mathrm{NB}(W(u))=\mathrm{B}(Y(o))=\mathrm{NB}+\mathrm{B}(W(u)+Y(o))$

Verse 2, $\mathrm{V}(2)=\{2 \mid 2$ = Non-action (Wuwei) = Yinyang = Beauty, Goodness; Difficulty and Easiness; Longness and Shortness; Highness and Lowness; Tones and Voices; Front and Behind $\}$; in short, V(2) = $\mathrm{N}(\mathrm{a})(\mathrm{Ww})=\mathrm{Yy}$

Verse 3, $\mathrm{V}(3)=\{3 \mid 3=$ Non-action $($ Wuwei $)=$ No Appreciation of Wise $\}$; in short, $\mathrm{V}(3) \mathrm{N}(\mathrm{a})(\mathrm{Ww})=$ NAW

Verse $4, \mathrm{~V}(4)=\{4 \mid 4=$ Dao $=$ Hollow/Empty $=$ Living With Light and Dust $=$ Infinite $=$ Nameless $=$ Shapeless $)\}$; in short, $\mathrm{V}(4)=\mathrm{D}(\mathrm{a})=\mathrm{H}(\mathrm{o}) / \mathrm{E}(\mathrm{m})=\mathrm{LLD}=\mathrm{I}=\mathrm{N}=\mathrm{S}$

Verse $5, \mathrm{~V}(5)=\{5 \mid 5=$ Heaven, Earth, Humans, All Things, Hollow $=$ Fairness $=$ Stillness $\}$; in short, V(5)= $\mathrm{H}(\mathrm{e})+\mathrm{E}(\mathrm{a})+\mathrm{H}(\mathrm{u})+\mathrm{AT}+\mathrm{H}(\mathrm{o})=\mathrm{F}=\mathrm{S}$

Verse $6, \mathrm{~V}(6)=\{6 \mid 6=\mathrm{Dao}=$ Profound Vagina $\}$; in short, $\mathrm{V}(6)=\mathrm{D}(\mathrm{a})=\mathrm{PV}$

Verse 7, $\mathrm{V}(7)=\{7 \mid 7=$ Dao of Human $=$ Selfishless $\}$; in short, $\mathrm{V}(6)=\mathrm{DH}=\mathrm{S}(1)$

Verse $8, \mathrm{~V}(8)=\{8 \mid 8=$ Water $=$ Benefit All for Nothing $\}$; in short, $\mathrm{V}(8)=\mathrm{W}=\mathrm{BAN}$ 
Verse 9, $\mathrm{V}(9)=\{9 \mid 9=$ No Extremes $\}$; in short, $\mathrm{V}(9)=\mathrm{NE}$

Verse $10, \mathrm{~V}(10)=\{10 \mid 10=$ One $=$ Unity $=$ Body, Mind, Soul $=$ Grand Virtue $\}$; in short, $\mathrm{V}(10)=\mathrm{O}=\mathrm{U}=\mathrm{B}$ $+\mathrm{M}+\mathrm{S}=\mathrm{GV}$

Verse 11, $\mathrm{V}(11)=\{11 \mid 11=$ Hollow $=$ Nihility $\}$; in short, $\mathrm{V}(11)=\mathrm{H}=\mathrm{N}$

Verse $12, \mathrm{~V}(12)=\{12 \mid 12=$ Mind Cultivation $=$ Simplicity $=$ Organic $\}$; in short, $\mathrm{V}(12)=\mathrm{MC}=\mathrm{S}=\mathrm{O}$

Verse $13, \mathrm{~V}(13)=\{13 \mid 13=$ Life Value $=$ No Favor, No Disgrace $=$ Otherness $\}$; in short, $\mathrm{V}(13)=\mathrm{LV}=\mathrm{NF}$ $+\mathrm{ND}=\mathrm{O}$

Verse 14, V(14) $=\{14 \mid 14=$ Dao (Property) $=$ Invisible, Inaudible, Intangible $\}$; in short, $\mathrm{V}(14)=\mathrm{D}(\mathrm{p})=\mathrm{I}(\mathrm{v})$ $+\mathrm{I}(\mathrm{a})+\mathrm{I}(\mathrm{t})$

Verse $15, \mathrm{~V}(15)=\{15 \mid 15=$ Daoist $=$ Profound, Simple $\}$; in short, $\mathrm{V}(15)=\mathrm{P}+\mathrm{S}$

Verse $16, \mathrm{~V}(16)=\{16 \mid 16=$ Void, Peace $\}$; in short, $\mathrm{V}(16)=\mathrm{V}+\mathrm{P}$

Verse $17, \mathrm{~V}(17)=\{17 \mid 17=$ Non-action $\}$; in short, $\mathrm{V}(17)=\mathrm{N}(\mathrm{a})$

Verse 18, $\mathrm{V}(18)=\{18 \mid 18=$ Opposite and Complementary $\}$; in short, $\mathrm{V}(18)=\mathrm{O}+\mathrm{C}$

Verse 19, V(19) $=\{19 \mid 19=$ Plainness, Simplicity; Little Selfishness, Little Desire; Ignorance, Non-worry $\}$; in short, $\mathrm{V}(19)=\mathrm{PS}+\mathrm{L}(\mathrm{s}) \mathrm{LD}+\mathrm{IN}(\mathrm{w})=$ PSLLDIN

Verse 20, $\mathrm{V}(20)=\{20 \mid 20=$ Plainness $\}$; in short, $\mathrm{V}(19)=\mathrm{P}$

Verse 21, V $(21)=\{21 \mid 21=$ Dao's D $(e)=$ Great Character $=$ Huanghu $=$ Evasive/Elusive $\} ;$ in short, $\mathrm{V}(21)=$ $\mathrm{DD}(\mathrm{e})=\mathrm{GC}=\mathrm{H}(\mathrm{h})=\mathrm{E}$

Verse 22, $\mathrm{V}(22)=\{22 \mid 22=$ Yield $\}$; in short, $\mathrm{V}(22)=\mathrm{Y}$

Verse 23, $\mathrm{V}(23)=\{23 \mid 23=$ Modest Wording $\}$; in short, $\mathrm{V}(23)=\mathrm{MW}$

Verse 24, V(24) $=\{24 \mid 24=$ Firm $=$ Non-stride $\}$; in short, $\mathrm{V}(24)=\mathrm{F}=\mathrm{NS}$

Verse25, $\mathrm{V}(25)=\{25 \mid 25=$ Spontaniety $=$ Bigness $=\mathrm{Dao}=\mathrm{D}($ existence $)+\mathrm{D}($ movement $)=$ Dao + Heaven + Earth + Human $\}$; in short, $\mathrm{V}(25)=\mathrm{S}(\mathrm{p})=\mathrm{B}=\mathrm{D}(\mathrm{a})=\mathrm{D}(\mathrm{e})+\mathrm{D}(\mathrm{m})=\mathrm{D}(\mathrm{a})+\mathrm{H}(\mathrm{e})+\mathrm{E}(\mathrm{a})+\mathrm{H}(\mathrm{u})$

Verse 26, V(26) $=\{26 \mid 26=$ Antithesis = Light, Heavy, Calm, Impetuous $\}$; in short, $\mathrm{V}(26)=\mathrm{A}(\mathrm{t})=\mathrm{L}+\mathrm{H}+$ $\mathrm{C}+\mathrm{I}$

Verse 27, $\mathrm{V}(27)=\{27 \mid 27=$ Non-action $=$ Actionless Enlightment $\} ;$ in short, $\mathrm{V}(27)=\mathrm{N}(\mathrm{a})=\mathrm{AE}$

Verse $28, \mathrm{~V}(28)=\{28 \mid 28=$ Babylike $=$ Humble $=$ Organic $=$ Harmony $\} ;$ in short, $\mathrm{V}(28)=\mathrm{B}(\mathrm{l})=\mathrm{H}(\mathrm{u})=\mathrm{O}$ $=\mathrm{H}(\mathrm{a})$

Verse 29, V(29) $=\{29 \mid 29=$ No Extremes, No Extravagance, No Pride $\}$; in short, $\mathrm{V}(29)=\mathrm{NE}+\mathrm{NP}$

Verse 30, $\mathrm{V}(30)=\{30 \mid 30=$ Dao of Arms $=$ No Abuse of Arms $=\mathrm{DA}=\mathrm{NAA}\}$; in short, $\mathrm{V}(30)=\mathrm{DA}=\mathrm{NAA}$

Verse $31, \mathrm{~V}(31)=\mathrm{V}(31)=\{31 \mid 31=$ Dao of Arms $=$ Non-arms + Restrict of Arms $\} ;$ in short, $\mathrm{V}(31)=\mathrm{DA}=$ $\mathrm{NA}+\mathrm{RA}$

Verse 32, V(32) $=\{32 \mid 32=$ Dao's Nameless $=$ Simplicity $\} ;$ in short, $\mathrm{V}(32)=\mathrm{DN}=\mathrm{S}$

Verse 33, $\mathrm{V}(33)=\{33 \mid 33=$ Human Life $=$ Self-known $=$ Self-conquer $\}$; in short, $\mathrm{V}(33)=\mathrm{HL}=\mathrm{S}(\mathrm{k})=\mathrm{S}(\mathrm{c})$

Verse 34, V(34) $=\{34 \mid 34=$ Dao 's Role $=$ Nurturing All Free $\}$; in short, V(34) $=\mathrm{DR}=\mathrm{NAF}$

Verse 35, V(35) $=\{35 \mid 35=$ Dao 's Ode $=$ Simplicity $\}$; in short, $\mathrm{V}(35)=\mathrm{DO}=\mathrm{S}$

Verse 36, $\mathrm{V}(36)=\{36 \mid 36=$ No Extreme $=$ Extremes With Opposites $=$ Weakness Over Strength $\}$; in short, $\mathrm{V}(35)=\mathrm{NE}=\mathrm{E}(\mathrm{w}) \mathrm{O}=\mathrm{W}(\mathrm{o}) \mathrm{S}$

Verse $37, \mathrm{~V}(37)=\{37 \mid 37=$ Action with Non-action $=$ Spontaneity $\}$; in short, $\mathrm{V}(37)=\mathrm{A}(\mathrm{w}) \mathrm{N}(\mathrm{a})=\mathrm{S}(\mathrm{p})$ 
Verse 38, V(38) $=\{38 \mid 38=$ Dao's Derivative $=$ Dao, De, Humanity, Justice $\}$; in short, $\mathrm{V}(37)=\mathrm{D}(\mathrm{a}) \mathrm{D}(\mathrm{r})=$ $\mathrm{D}(\mathrm{a})+\mathrm{D}(\mathrm{e})+\mathrm{H}(\mathrm{u})+\mathrm{J}(\mathrm{u})$

Verse 39, $\mathrm{V}(39)=\{39 \mid 39=$ Dao 's Popularity $=$ Oneness $\}$; in short, $\mathrm{V}(39)=\mathrm{D}(\mathrm{a}) \mathrm{P}=\mathrm{O}$

Verse 40, V(40) $=\{40 \mid 40=$ Dao 's Changing Rule, Dao's Breeding $=$ Return + Weakness = Being, Non-being $\}$; in short, $\mathrm{V}(40)=\mathrm{D}(\mathrm{a}) \mathrm{CR}+\mathrm{D}(\mathrm{a}) \mathrm{B}=\mathrm{R}+\mathrm{W}=\mathrm{B}+\mathrm{NB}$

Verse 41, V(41) $=\{41 \mid 41=$ Responses to Dao $=$ Dao 's Essence + Dao's Surface $=$ the Popularity of Contradiction $\}$; in short, $\mathrm{V}(41)=\mathrm{RD}(\mathrm{a})=\mathrm{D}(\mathrm{a}) \mathrm{E}+\mathrm{D}(\mathrm{a}) \mathrm{S}=\mathrm{PC}$

Verse 42, V(42) $=\{42 \mid 42=$ Dao Fertility = Dao: One, Two, Three, Myriads $\}$; in short, V(42) $=\mathrm{D}(\mathrm{a}) \mathrm{F}=\mathrm{D}(1)$ $+\mathrm{D}(2)+\mathrm{D}(3)+\mathrm{D}(\mathrm{m})$

Verse $43, \mathrm{~V}(43)=\{43 \mid 43=$ Tenderness, Weakness $=$ Non-action $=$ Non-words $\} ;$ in short, $\mathrm{V}(43)=\mathrm{T}+\mathrm{W}=$ $\mathrm{N}(\mathrm{a})+\mathrm{N}(\mathrm{w})$

Verse $44, \mathrm{~V}(44)=\{44 \mid 44=$ Fame, Wealth $=$ Self-content $\} ;$ in short, $\mathrm{V}(44)=\mathrm{F}+\mathrm{W}=\mathrm{S}(\mathrm{c})$

Verse $45, \mathrm{~V}(45)=\{45 \mid 45=$ Character $=$ Inversion $\}$; in short, $\mathrm{V}(45)=\mathrm{C}=\mathrm{I}$

Verse $46, \mathrm{~V}(46)=\{46 \mid 46=$ Self-content $\}$; in short, $\mathrm{V}(46)=\mathrm{S}(\mathrm{c})$

Verse $47, \mathrm{~V}(47)=\{47 \mid 47=$ Epistemology $=$ Self-cultivation $=$ Soul Purification $\} ;$ in short, $\mathrm{V}(47)=\mathrm{E}=\mathrm{S}(\mathrm{c})$ $=\mathrm{SP}$

Verse $48, \mathrm{~V}(48)=\{48 \mid 48=$ Learning, Daoing = Doing with Non-action $\}$; in short, $\mathrm{V}(48)=\mathrm{L}+\mathrm{D}(\mathrm{ag})=\mathrm{D}(\mathrm{g})$ $+\mathrm{N}(\mathrm{a})$

Verse $49, \mathrm{~V}(49)=\{49 \mid 49=$ Sage $=$ Otherness $=$ Babylike $\} ;$ in short, $\mathrm{V}(49)=\mathrm{S}=\mathrm{O}=\mathrm{B}(\mathrm{l})$

Verse $50, \mathrm{~V}(50)=\{50 \mid 50=$ Life $=$ Simple, Pure, Still $=$ No Self-spoil $\}$; in short, V(50)=L $=\mathrm{S}+\mathrm{P}+\mathrm{S}=$ $\mathrm{NS}(\mathrm{s})$

Verse 51, V(51) $=\{51 \mid 51=$ Dao's Respect, De's Value $=$ Profound Virtue $\}$; in short, V(51) $=\mathrm{D}(\mathrm{a}) \mathrm{R}+$ $\mathrm{D}(\mathrm{e}) \mathrm{V}=\mathrm{PV}$

Verse 52, $\mathrm{V}(52)=\{52 \mid 52=$ Root Reserved $=$ Dao + Children $($ Derivatives $)\} ;$ in short, $\mathrm{V}(52)=\mathrm{RR}=\mathrm{D}(\mathrm{a})+$ $\mathrm{C} / \mathrm{D}(\mathrm{r})$

Verse $53, \mathrm{~V}(53)=\{53 \mid 53=$ Great Dao $\}$; in short, $\mathrm{V}(53)=$ GD

Verse 54, V(54) $=\{54 \mid 54=$ Dao's Function $=$ De's Performance $=$ Self-cultivation $\}$; in short, $\mathrm{V}(54)=$ $\mathrm{D}(\mathrm{a}) \mathrm{F}=\mathrm{D}(\mathrm{e}) \mathrm{P}=\mathrm{S}(\mathrm{c})$

Verse 55, V(55) $=\{55 \mid 55=$ Life Philosophy $=$ De's Performance $=$ Babylike $\}$; in short, $\mathrm{V}(55)=\mathrm{LP}=\mathrm{D}(\mathrm{e}) \mathrm{P}$ $=\mathrm{B}(1)$

Verse 56, $\mathrm{V}(56)=\{56 \mid 56=$ Normal Harmony $=$ Mysterious Harmony $\}$; in short, $\mathrm{V}(56)=\mathrm{NH}=\mathrm{MH}$

Verse $57, \mathrm{~V}(57)=\{57 \mid 57=$ Common Dao $=$ Non-action $\}$; in short, $\mathrm{V}(57)=\mathrm{CD}=\mathrm{N}(\mathrm{a})$

Verse $58, \mathrm{~V}(58)=\{58 \mid 58=$ Antithesis $=$ Exchanges of Suffering and Happiness $\}$; in short, $\mathrm{V}(58)=\mathrm{A}(\mathrm{t})=$ $\mathrm{E}(\mathrm{o}) \mathrm{SH})$

Verse $59, \mathrm{~V}(59)=\{59 \mid 59=$ Governing $/$ Immorality $=$ Sparing $\}$; in short, $V(59)=\mathrm{G} / \mathrm{I}=\mathrm{S}(\mathrm{p})$

Verse $60, \mathrm{~V}(60)=\{60 \mid 60=$ Dao of Politics $=$ Non-action, Non-disturbing; in short, $\mathrm{V}(60)=\mathrm{D}(\mathrm{a}) \mathrm{P}=\mathrm{N}(\mathrm{a})+$ $\mathrm{N}(\mathrm{d})$

Verse $61, \mathrm{~V}(61)=\{61 \mid 61=$ Dao of Politics $=$ Self-lowering $\}$; in short, $\mathrm{V}(61)=\mathrm{D}(\mathrm{a}) \mathrm{P}=\mathrm{S}(1)$

Verse $62, \mathrm{~V}(62)=\{62 \mid 62=$ Dao of Human Relationship $=$ Open to All $\}$; in short, $\mathrm{V}(62)=\mathrm{D}(\mathrm{o}) \mathrm{HR}=\mathrm{OA}$ 
Verse 63, V(63) $=\{63 \mid 63=$ Action in Non-action $=$ Thankfulness Over Revenge, Smallness, Minuteness, Carefulness $\}$; in short, $\mathrm{V}(63)=\mathrm{AN}(\mathrm{a})=\mathrm{T}(\mathrm{o}) \mathrm{R}+\mathrm{S}+\mathrm{M}+\mathrm{C}$

Verse 64, V(64) $=\{64 \mid 64=$ Precaution, Planning, Perseverance $\}$; in short, $\mathrm{V}(64)=\mathrm{P}+\mathrm{P}+\mathrm{P}$

Verse $65, \mathrm{~V}(65)=\{65 \mid 65=$ Dao of Governing $=$ Profound De $\}$; in short, $\mathrm{V}(65)=\mathrm{D}(\mathrm{a}) \mathrm{G}=\mathrm{PD}(\mathrm{e})$

Verse $66, \mathrm{~V}(66)=\{66 \mid 66=$ Forbearance $=$ No-contending $\} ;$ in short, $\mathrm{V}(66)=\mathrm{F}=\mathrm{N}(\mathrm{c})$

Verse $67, \mathrm{~V}(67)=\{67 \mid 67=$ Definition of Dao $=$ Three Treasures $=$ Love, Save, Modest $\}$; in short, V(67)= $\mathrm{DD}(\mathrm{a})=\mathrm{TT}=\mathrm{L}+\mathrm{S}+\mathrm{M}$

Verse $68, \mathrm{~V}(68)=\{68 \mid 68=$ Dao of Arms $=$ No-contending $=$ No-fighting $\} ;$ in short, $\mathrm{V}(68)=\mathrm{D}(\mathrm{a}) \mathrm{A}=\mathrm{N}(\mathrm{c})$ $=\mathrm{N}(\mathrm{f})$

Verse $69, \mathrm{~V}(69)=\{69 \mid 69=$ Restriction of Arms $=$ No-striving $=$ No-fighting $\} ;$ in short, $\mathrm{V}(69)=\mathrm{R}(\mathrm{o}) \mathrm{A}=$ $\mathrm{N}(\mathrm{s})=\mathrm{N}(\mathrm{f})$

Verse $70, \mathrm{~V}(70)=\{70 \mid 70=$ Integrity of Knowledge and Action $\}$; in short, $\mathrm{V}(70)=\mathrm{IKA}$

Verse $71, \mathrm{~V}(71)=\{71 \mid 71=$ Self-knowing $=$ Humbleness $\}$; in short, $\mathrm{V}(71)=\mathrm{S}(\mathrm{k})=\mathrm{H}$

Verse 72, $\mathrm{V}(72)=\{72 \mid 72=$ Civilian Love $\}$; in short, $\mathrm{V}(72)=\mathrm{CL}$

Verse 73, V(73) $=\{73 \mid 73=$ Weakness, Spontaneity, Non-action $=$ Weakness Over Strongness $\}$; in short, $\mathrm{V}(73)=\mathrm{W}(\mathrm{n})+\mathrm{S}(\mathrm{p})+\mathrm{N}(\mathrm{a})=\mathrm{W}(\mathrm{o}) \mathrm{S}$

Verse 74, V(74) $=\{74 \mid 74=$ Dao of Governance $=$ No Severe Law; in short, V(74) $=\mathrm{D}(\mathrm{a}) \mathrm{G}=\mathrm{NSL}$

Verse $75, \mathrm{~V}(75)=\{75 \mid 75=$ No Extreme Action $\}$; in short, $\mathrm{V}(75)=$ NEA

Verse 76, V(76) $=\{76 \mid 76=$ Weakness Over Strongness $\}$; in short, V(76) $=\mathrm{W}(\mathrm{o}) \mathrm{S}$

Verse $77, \mathrm{~V}(77)=\{77 \mid 77=$ Dao of Heaven $=$ Fairness $\}$; in short, $\mathrm{V}(77)=\mathrm{D}(\mathrm{a}) \mathrm{H}=\mathrm{F}$

Verse 78, V(78) $=\{78 \mid 78=$ Water's Tenderness $=$ Yieldness $=$ Insult Embrace $\} ;$ in short, $\mathrm{V}(78)=\mathrm{WT}=\mathrm{Y}$ $=\mathrm{IM}$

Verse 79, $\mathrm{V}(79)=\{79 \mid 79=$ Kindness $=$ Reason Over Emotions $\}$; in short, $\mathrm{V}(79)=\mathrm{K}=\mathrm{R}(\mathrm{o}) \mathrm{E}$

Verse $80, \mathrm{~V}(80)=\{80 \mid 80=$ Paradise $=$ Joyful Community $=$ Small Area, Fewer People $\} ;$ in short, V $(80)=\mathrm{P}$ $=\mathrm{JC}=\mathrm{SA}+\mathrm{FP}$

Verse $81, \mathrm{~V}(81)=\{81 \mid 81=$ Trueness, Kindness, Beauty $=$ Benefit Without Harm, Do Without Contending $\} ;$ in short, $\mathrm{V}(81)=\mathrm{T}+\mathrm{K}+\mathrm{B}=\mathrm{BWH}+\mathrm{DWC}(\mathrm{Qi} \& \mathrm{Li}, 2016)$

The capital letters and the small ones above are struggling for agreements; some of them disagree for the harmony within the verse itself.

It is argued that the DDC is divided into two parts, Chings of Dao and De. The first 37 verses are of Dao, and the latter part is De (Gan, 2016, p. 3). Sure, there exist a variety of views about this split. Theoretically and superficially, in terms of the wording, Dao $=\{1,4,8,9,14,15,16,18,21,24,25,30,31,32,34,35,39,40,41$, $42,46,47,48,52,53,57,62,65,67,81\}, \mathrm{De}=\{21,38,54,59,68\}, \mathrm{Dao} \& \mathrm{De}=\{23,41,49,51,55,60,79\}$, Profound De $=\{10,38,51\}$, Non-action $=\{3,37,48,57,63,64\}$, Yin, Yang $=\{42\}$, Politics $=\{60,61\}$, Dao of Arms $=\{31,69\}$, Dao of Heaven $=\{47,59,77\}$, Water $=\{8,78\}$, Dao of Forbearance $=\{66,68,69\}$, Dao of Self-content $=\{44,46\}$, Dao of Antithesis $=\{2,3,11,22,26,28,36,39,40,42,43,44,45,50,52,56,57,58,61$, $64,68,71,72,73,76,78,81\}$, Dao of Spontaneity (Ziran) $=\{17,23,25,64\}$, Dao of Simplicity $($ Su \& Pu $)=\{19$, $28,32,37\}$, Dao of Baby $=\{20,28\}$, Dao of Common People $=\{72,74,75,80\}$.

This kind of property is classified with the surperficial meaning, otherwise all of which are of Dao. 


\section{Group Theory and DDC}

In mathematics, a group is a set equipped with a binary operation which combines any two elements to form a third element in such a way that four conditions called group axioms are satisfied, namely closure, associativity, identity, and invertibility (Group (mathematics)—Wikipedia, n.d.).

For any two integers $\mathrm{a}$ and $\mathrm{b}$, the sum $\mathrm{a}+\mathrm{b}$ is also an integer. For instance, Dao $+\mathrm{De}=\mathrm{Dao}$ De, Yin + Yang $=$ Yinyang $=$ Qi. Dao + Heaven $=$ Dao of Heaven, De + Things $=$ De of Things, Yin + mountains $=$ Yin of Mountain, Yang + Water $=$ Yang of Water. Dao combined De can be interpreted as Dao De, though they are not simply the addition of the former two which is the integrity of human beings or other objects. Yin and Yang is the harmony of Qi. Dao going along with Heaven is the Dao of Heaven; De with things is the De of things. Yin combined with mountains is the Yin of mountains. Yang added by water is the Yang of water. This is the property of closure.

For all integers $a, b$, and $c,(a+b)+c=a+(b+c) \ldots$ a property known as associativity. (Dao + De $)+$ Heaven/Earth/Human $=$ Dao $+($ De + Heaven/Earth/Human $)$. Heaven, earth, or human is combined with Dao and De, which is paralleled with the big three's De together with Dao.

If $\mathrm{a}$ is any integer, then $0+\mathrm{a}=\mathrm{a}+0=\mathrm{a}$. Dao(0) + Heaven/Earth/Human $=$ Heaven/Earth/Human $+\operatorname{Dao}(0)$ $=$ Heaven/Earth/Human. Dao is invisiable, like zero, nihility; this number can make any number keep itself.

For every integer $a$, there is an integer $b$, such that $a+b=b+a=0$. The integer $b$ is called the inverse element of the integer a and is denoted $-\mathrm{a}$. Dao + Heaven/Earth/Human $=$ Heaven $/$ Earth $/$ Human + Dao $=$ Dao $(0)$. Dao, Yinyang, blurred object, b, can be the inverse element of all things.

Dao, De, Dao De, Yin, Yang, Yinyang, You, Wu, Youwu, all can be groups, which bear the property of such concepts.

\section{The Fuzzy Set of DDC}

A fuzzy set is a class of objects with a continuum of grades of membership. Such a set is characterized by a membership (characteristic) function which assigns to each object a grade of membership ranging between zero and one. The notions of inclusion, union, intersection, complement, relation, convexity, etc., are extended to such sets, and various properties of these notions in the context of fuzzy sets are established (Zadeh, 2005, p. 3). Dao and De are obscure, vague, almost no absolute interpretation. How can DDC be classified? What information can be proceeded? Can it be articulated with fuzzy sets?

The typical fuzzy set of $\{0,1\}$ can be applied to a host of fields. Dao De Ching is a fuzzy one, of which Dao can be viewed as the element of 0 , De 1, and vice versa. This is the image that Dao which can be daoed is not the etynal Dao. Hence, Dao can be 0,1 , or any numbers. Plus, Yin can be considered as o, Yang 1. Dao De Ching $=\{0$, $1\}, \mathrm{f}(\mathrm{x})=\{\mathrm{x} \mid 0<\mathrm{x}<1, \mathrm{x} \in \mathrm{DDC}\} . \mathrm{f}(\mathrm{h})=\{\mathrm{h} \mid 0<\mathrm{h}<1, \mathrm{~h} \in \mathrm{DDC}\}$. It holds true to other key terms, such as Being and Non-being (You and Wu), action and non-action (Wuwei and Youwei), Qi, heaven, earth, humans, enlightenment and darkness, dynamic and static, hollow and firm, weak and strong, kind and evil, water and myriad things, bend and straight, baby and oneness(unity).

Non-being $(\mathrm{Wu})$ can be 0 , and being $(\mathrm{You})$ is smaller than 1 ; being is growing, from 0 to 1 . Hence, Dao = $\{\mathrm{wu}, \mathrm{you}\}, \mathrm{y}=\mathrm{f}(\mathrm{w})=\{\mathrm{w} \mid 0<\mathrm{w}<1, \mathrm{w} \in \mathrm{D}(\mathrm{a})\}$. Non-action (Wuwei) and Action (Youwei) can be illustrated in the same way. Energy (Qi) is changing all the time, up and down, which is also a fuzze set. Heaven and earth (HE) 
are o, humans are 1, whose growing and developing are from o to $1 . \mathrm{HE}=\mathrm{f}(\mathrm{hu})=\{\mathrm{h}(\mathrm{u}) \mid 0<\mathrm{h}(\mathrm{u})<1, \mathrm{~h}(\mathrm{u}) \in$ $\mathrm{HE}\}$. Enlightenment is of 1, darkness of 0. DDC $=$ \{darkness, enlightenment), $\mathrm{f}(\mathrm{d})=\{\mathrm{d} \mid 0<\mathrm{d}<1, \mathrm{~d} \in \mathrm{D}(\mathrm{a})\}$. DDC is a set of dynamic and static, of which dynamic (d) is 1, static (s) $0 ; \mathrm{S}=\mathrm{f}(\mathrm{d})=\{\mathrm{d} \mid 0<\mathrm{d}<1, \mathrm{~d} \in \mathrm{D}(\mathrm{a})\}$. Dao is moving between hollow and firm, hollow (h) o with firm (f) 1 ; $\mathrm{f}=\mathrm{f}(\mathrm{h})=\{\mathrm{h} \mid 0<\mathrm{h}<1$, $\mathrm{h} \in \mathrm{D}(\mathrm{a})\}$. Weak (0) and strong (1), a set of $\{\mathrm{w}, \mathrm{s}\}$, presents us with o over 1, 1 being from 0 , the root. Kind (0) and evil (1) are interdependent and interlinked, \{kind, evil $\}$ going along with our rising and setting. Water (0) and myriad (1) reveals o bearing 1,1 growing with 0 . Bend and straight, $\{0,1\}$, mutually support with the former the stem. Babies mean o, without any desire but playing for fun, whose simplicity can be oneness (1).

\section{Concluding Remarks}

Mathematics is a discipline that seeks the Dao and applys it. There are no specific ways for us to follow, no fixed solutions for every problem in the everyday life as for the mathematical problems. The rule of law, Dao, is empty.

The DDC could rightly be called the Chinese Bible (Rijckenborgh \& Petri, 1996, p. 23). The 81 verses of DDC talk about the one and wholeness of the Daoism, the universe, the one of cosmos, the human world and nature. Such a complete unified theory describes everything in the universe. This space is of the infinite, being and nothingness. Knowingly, pyramids are full of mysteries of math undiscovered (Zhang, 2017, p. 23). It holds true to DDC, a mental pyramid, based on Dao and De, which is crying for us to discover its mathematical myth.

To really understand what it means to think rationally, mathematics will need to team up with psychology and sociology, and perhaps even biology and poetry (Cole, 1999, p. 164). The poetic DDC, sociological verses, can go well along with math.

\section{Recommendations}

Can we dissect DDC in terms of mathematica functions? As we know, fucitonal analysis is of the most important approaches in math. Are coordinate systems working in tackling DDC? Will topology of algebra applicable to it? Do you want to witness mathematicl modeling's role in this Chinese Bible? Don't you believe this philosophical verse mirror more geometrical graphs?

The cosmos are full of nets; we are at the different knots at the different time. The position and location of all of us are variables with Dao and De moving. Our journey tells no shape or size, rectangular, ellipse, hyperbala, circle, or triangular. Who knows? Dao has it.

\section{References}

Broughton, J., \& Carriero, J. (Eds.). (2008). A companion to descartes. Malden: Blackwell Publishing.

Cole, K. C. (1999). The universe and teacup: The mathematics of truth and beauty. New York: A Harvest Book Harcourt, Inc.

Gan, Y. (2016). Yi's arguments of Dao De Ching. Beijing: Standards Press of China.

Group (mathematics) —Wikipedia. (n.d.). Retrieved from https://en.wikipedia.org/wiki/Group_(mathematics)

Qi, S. H., \& Li, Y. M. (2016). Hearty analysis of Dao De Ching. Dalian: Dongbei University of Finance \& Economics Press.

Rijckenborgh, J., \& Petri, C. (1996). The Chinese gnosis. Haarlem-The Netherlands: Rozekruis Pers.

Rudin, W. (2016). Principles of mathematical analysis. Beijing: China Machine Press.

Stark, H., \& Woods, J. W. (2012). Probability, statistics, and random processes for engineers (4th ed.). Beijing: Publishing House of Electronics Industry. 
Zadeh, L. A. (2005). Fuzzy sets and fuzzy information—granulation theory. (D. Ruan and C. F. Huang, Eds.). Beijing: Beijing Normal University Press.

Zhang, J. Z. (2011). Mathematics and philosophy. Beijing: China Children Publishing House.

Zhang, R. J. (2017). Mathematical ideas and cultures. Beijing: Science Press. 